\title{
Notas (Para a economia de Raul Brandão)
}

Gustavo Rubim

(Universidade Nova de Lisboa)

\section{RESUMO}

Articulando os vários sentidos da palavra "nota" associados à ideia de valor com a indicação, dada por Raul Brandão numa nota prévia ao livro As Ilhas Desconhecidas (1926), de que ele é composto por "notas de viagem", o ensaio concentra-se numa leitura dos dois primeiros capítulos do relato para neles desdobrar todas as implicações do tema da economia. Tais implicações são pensadas no quadro da ligação entre literatura e antropologia que se propõe, contra Foucault, como articulação axial para a definição da modernidade.

PALAVRAS-CHAVE: Nota, Valor, Etnografia.

\section{ABSTRACT}

Connecting the several meanings of the word "note" that express the idea of value to the statement made by Raul Brandão that his travel book As Ilhas Desconhecidas (1926) is mainly written through "travel notes", this essay is focused on a careful reading of all the implications of the theme of economy along the two first chapters of that Brandão's book. Those implications are analysed in a frame of thought that asserts, against Foucault, that the articulation linking literature to anthropology is crucial for any definition of modernity.

KEYWORDS: Note, Value, Ethnography. 
E não sei dizer-te o que me custa mais, se morrer, se ver destruída a Companhia Geral dos Depósitos. Ó meu Deus, como me dói a barriga!...

Os desenlaces precipitam-se. [...] Raul Brandão, O Pobre de Pedir

Talvez não seja indiferente, não é decerto acaso que em português (e, claro, nunca é só em português) usemos a mesma palavra para designar o apontamento escrito e a unidade de papel-moeda, a avaliação académica e o sinal ou o signo que representa a duração e a altura de um som musical. Antes que o saibamos pensar ou explicar, a língua estabelece laços, claros ou obscuros que sejam, entre o discurso e a economia, entre o valor intelectual e a experiência estética. No cruzamento de tudo isso - e de mais — está a nota, estão as notas, porque parece melhor dizer no plural aquilo que não se deixa em momento nenhum reduzir à unidade.

Mas se se deixasse ou se ao menos o tentássemos, o que iríamos encontrar, com o apoio da etimologia, seria a marca ou a inscrição sem a qual aparentemente nenhum dos sentidos da nota se conserva viável, nem mesmo o da nota ou detalhe feliz (ou lamentável), por exemplo, na ocasião de uma festa pública. A nota nunca abandona, nunca se desprende do campo da escrita e não só não se deixa regular por uma estrita e supostamente nítida demarcação entre uma escrita que seria literal (quer dizer, efetivamente gráfica) e outra que seria apenas figurada ou derivada, como ainda é ela que tende a regular por dentro essa mesma oposição através de dois conceitos que sem a nota não existiriam: a denotação e a conotação. No fim de contas, aliás, a própria ciência etimológica teria de reconhecer uma certa dívida face à nota, quanto mais não fosse pelo registo que ela mesma faz da significação de "annotatio, annotationis" (em latim) enquanto "etimologia", precisamente.

Em todo este jogo, sempre anterior à nossa vontade de falantes e portanto sempre em princípio mais poderoso que o nosso poder de o controlar, a escrita ou a marca é simultaneamente o que junta e o que separa os vários sentidos da nota: da simples anotação à notabilidade ou notoriedade, da nódoa à notificação ou à assinatura (subnotatio, em latim, uma vez mais), o que recebemos da e na língua é já a proliferação das notas como movimento indissociável da disseminação do sentido e das suas marcas. E tal proliferação, como tal movimento, não apresenta o roteiro das suas orientações, o mapa dos percursos programáveis ou previsíveis que a nota pode seguir, nem o regulamento das hierarquias em que se pode inscrever ou que, sobretudo, tende a criar ou instituir, segundo o paradigma hoje praticamente mundializado das avaliações escolares. Entre a repetição e dispersão das notas na língua, por um lado, e certo caos da experiência do mundo, por outro, a relação é ao mesmo tempo de similaridade e de tensão, de analogia e de resistência, porque a nota tem em simultâneo qualquer coisa de provisório, de inacabado, de substitutivo ou de substituível $e$ um efeito regulador e distintivo que marca o ponto de aplicação de uma instância de poder, classificatória, delimitadora (por exemplo, entre o musical e o não musical, entre o valioso e o desprezível).

Onde há notas há sempre, portanto, direta ou indiretamente, um valor ou um jogo de valores que está em causa. E é o que acontece também, se bem que nun sentido que não tem de ser claro ou óbvio, quando alguém propõe um conjunto de notas para tratar, digamos, ensaisticamente, um dado tópico do 
pensamento ou da reflexão ou certo tema que, de uma maneira ou de outra (a descobrir, a indicar), se encontra numa obra. Essas notas sugerem tanto o caráter provisório, talvez propedêutico da proposta exploratória, quanto o valor que se atribui ao pouco que elas avançam, numa economia de escrita ou de discurso em que dizer menos sinaliza o cuidado com o que (potencialmente) significa ou virá a significar muito. As notas são, nesse sentido, simultaneamente, aposta e garantia do duplo valor do que se escreve e do sobre que se escreve, ainda que sejam apenas primeiras notas ou notas prévias, preliminares (prenotações, seria aqui o termo adequado), ou até notas soltas cujo valor intrínseco, afinal, dispensa e relativiza o valor da organização em conjunto, da sistematização que no entanto não proíbem e até podem prometer melhor, adiando.

A esta regra muito genérica não escapam inteiramente as notas que estou aqui a lançar em vista de uma economia de Raul Brandão, que elas pretendem começar a apreender, se bem que não se possam dizer em rigor preliminares ou iniciais. Mesmo na qualidade de apontamentos, são já um retorno: à obra de Brandão e a um texto específico a partir do qual já noutra ocasião tentei levantar ou puxar uma linha de leitura que, não sendo económica por definição, passa pela economia e de um modo nem acidental nem fortuito. Se há alguma coisa de estranho nesta conexão de Brandão com a economia é justamente que ela esteja ainda tão à espera de ser lida, não direi a fundo, mas antes à superfície, a superfície imediata de títulos como Os Pobres ou O Pobre de Pedir, que nos chegam, praticamente alheios a comentários e interpretações, quase intactos no seu enigma ou na sua evidência.

E daí estas anotações ao texto de As Ilhas Desconhecidas, o livro de 1926 que também tem na economia - sobretudo a açoriana, mas também a madeirense e espero mostrar que nem só essas duas - um dos seus eixos mais obsessivos.

\section{2.}

Ainda um ponto de etimologia, antes de avançar. Tem que ver com o que se poderia designar o fabrico do livro, tanto quanto com a sua retórica de livro de viagens.

O livro (que, convém não esquecer, traz em subtítulo: "Notas e Paisagens"), diz Raul Brandão na nota prévia "Em Três Linhas", faz-se precisamente com "notas", poupando nos acabamentos: "Este livro éfeito com notas de viagem, quase sem retoques. Apenas ampliei um ou outro quadro, procurando sempre não tirar a frescura às primeiras impressões." As notas são aqui matéria-prima do livro e princípio de escrita: princípio da escrita em viagem como inscrição (ou impressão) de "primeiras impressões". É preciso não passar a correr por cima da palavra "impressões" através da qual se diz ao mesmo tempo a marca da experiência de viajar no viajante e a escrita que capta essa marca na proximidade, dir-se-ia imediata, da sua inscrição. As notas (de viagem) preservadas guardam, vigiam, prometem ou garantem que essa proximidade não é afetada pela instância mediadora - retórica, artística - da composição do livro. Há aí um princípio de verdade a funcionar, mas uma verdade que não é propriamente da ordem do saber ou do conhecimento. Com efeito, notas e impressões conjugam-se numa lógica que a etimologia tenta elucidar quando explica que nem o antepositivo "not-" nem os seus derivados latinos têm parentesco com o verbo "(g)nosco" que, no entanto, explica o mesmo mas diferente antepositivo "not-" na sua segunda acepção derivada de "notus, nota, notum" (com o significado de "conhecido, reconhecido, manifestado, averiguado"1). Essa lógica é a do contacto sem o qual não há impressão e em função do qual o valor da impressão se mede exclusivamente pela sua "frescura", 
quer dizer, pela sua contiguidade com o momento e a singularidade do contacto, em princípio irrepetível. Não é portanto grande a distância entre o sentido científico da impressão como "ação de um objeto sobre a sensibilidade" (Houaiss) e a significação literária das "primeiras impressões" a que Raul Brandão neste livro não quer "tirar a frescura". É dessa marca deixada na sensibilidade que o livro, "quase sem retoques", deve fazer-se veículo e arquivo. Para a literatura, há uma verdade da marca — e uma escrita para essa verdade.

\section{3.}

As notas desta viagem não valem, porém, só pela experiência que pretendem partilhar: há um valor específico que as próprias notas se destinam a aferir, se não a criar, um valor anterior à viagem mas que requer e motiva a viagem, um valor que é, como todos os valores, comparativo. Já chamei a atenção, noutro contexto (cf. RUBIM, 2008, p. 111), para essa comparação entre o valor da paisagem japonesa e da paisagem açoriana que surge, na mesma nota "Em Três Linhas", atribuída a um oficial de marinha: "Tinha ourido a um oficial de marinha que a paisagem do arquipélago valia a do Japão. E talvez valha..." Esta formulação dubitativa não exprime apenas a impossibilidade de comparar por parte de quem não conhece o Japão nem o ceticismo de quem já conhece a paisagem açoriana; exprime sobretudo uma dúvida sobre o valor da comparação feita como se fizesse sentido comparar paisagens sem "notas" a suportar ou a intermediar a comparação: é a escrita a moeda que permite decidir o valor das paisagens. Se a nota pressupõe o livro já escrito que apresenta na brevidade das suas "três linhas" (gesto economizador que faz desta nota só uma passagem para as "notas de viagem" de que o livro se faz, mas que não permite ao leitor poupar-se a essa passagem), a sugestão é então a de que o livro "faz com os Açores o que outros fizeram com o Japão" (RUBIM, 2008, p. 111) e a alusão ao oficial de marinha é quase suficiente para reenviar a Wenceslau de Moraes e ao seu vasto esforço escrito para erguer o valor do Japão. Este poder da escrita para instituir valor é, porém, ambivalente e nunca se glosa sem tocar ao mesmo tempo no seu impoder, qualquer que seja o sentido que se atribua à evocação desse impoder num local tão estrategicamente retórico como o da apresentação de um livro: e é difícil decidir com segurança que sentido podem ter as palavras finais da nota "Em Três Linhas", onde se misturam o desejo e a impossibilidade de operar com a escrita uma ação sobre o desejo dos leitores: "Não poder en pintar com palarras alguns dos sitios mais pitorescos das ilhas, despertando nos leitores o desejo de os verem com os seus próprios olhos!..." Comparação e valor deixam sempre, portanto, as notas numa posição de valor de troca, engrenam a escrita, as palavras e o livro num jogo de circulação e substituição em que a verdade está ao mesmo tempo neles e desde sempre (e para sempre) fora deles. Nesta economia em que as palavras estão por pinturas e as pinturas estão pelos sítios que seriam já de si "pitorescos" - próprios portanto para uma conversão em pintura e nessa medida, portanto, impróprios, como se em si mesmos fossem já representações de si mesmos -, a adequação ou ajustamento das coisas às palavras (e, evidentemente, vice-versa) é tão difícil e problemática como a coincidência das palavras com o limite das palavras quando a sua função é pintar ou anotar, o que é aqui praticamente o mesmo sem no entanto poder ser exatamente o mesmo. Deveríamos captar aqui uma espécie de poética, mas no sentido de uma lei da escrita quando a escrita é anotação e, em particular, quando é feita de "notas de viagem", como acontece com As Ilhas Desconhecidas mas sem que As Ilhas Desconhecidas possam aqui ser mais do que um exemplo ou uma instância incessantemente remetendo para toda a escrita que se apresenta sob essa forma. 
A escrita de viagem, incluindo a que se dá como sujeita às regras ou exigências da etnografia, participaria assim desta lei em que a linguagem é experimentada sobre o seu limite representacional e na esfera da qual, portanto, mesmo que discretamente (isto é, de maneira económica, poupada, reservada) está sempre em jogo, talvez mesmo em questão, o poder da linguagem e está sempre algures a gerar-se uma dobra em que a linguagem se representa a si mesma. Compreende-se, de imediato, que tal poética, impensável sem a literatura, é irredutível à literatura, se o gesto de reduzir à literatura fosse exequível — e nunca é precisamente pela impossibilidade de lhe traçar um limite que não se redobre para dentro ou para fora dela.

\section{4.}

Nesta rede de implicações, não é difícil demonstrar que a economia está por todo o lado no texto de As Ilhas Desconhecidas.

Logo no percurso que define o capítulo "De Lisboa ao Corvo" a economia surge sob a figura de um processo de perdas e ganhos no domínio dos transportes marítimos afetados por uma alteração que desencadeia um jogo de valorizações e desvalorizações em série:

A vida a bordo dos vapores perdeu todo o interesse da antiga navegação à vela: é a vida a bordo do Hotel Francfort com porteiro e tudo. Foi-se o encanto dos velhos navios com as vergas rangendo ao vento e o gajeiro sobe-que-sobe àquele mastro real. $O$ que vale é a agitação tremenda que não cessa, a água em vagalhões cada vez mais cinzentos e maiores, que as velhas de penante e plumas, sentadas de bombordo a estibordo, e que se atrevem com o oceano Atlântico, fazem o possível por amesquinhar. [...] Ar lívido, água revolta e uma grandez̧a com que não posso arcar. Mais escuro... [...] Isto acaba por uma coisa negra e desmedida, por uma coisa ameaçadora e cheia de vozes, que o Hotel Francfort não consegue fazer esquecer com toda a sua banalidade. (BRANDÃO, s/d., p. 9-10, itálicos são meus.)

A transformação do navio a vapor (o "S. Miguel") em banal "Hotel Francfort" é um acontecimento no entanto surpreendente, se se tiver em conta que a narrativa começa, um escasso parágrafo antes, pela experiência de passagem de fronteiras que marca a identificação, talvez a única identificação possível da viagem como género literário específico. A última visão de terra, a transição da terra para o mar sem terra à vista é narrada como nada menos que uma mudança de mundo que começa com um fim do mundo: "Enquanto a gente vê terra, não tira os olhos - não pode - dum resto de areal, dum ponto violeta que desmaia e acaba por desaparecer na crista duma vaga. Um ponto e acabou o mundo. $\mathrm{O}$ nosso mundo agora é outro." (BRANDÃO, s/d., p. 9) Mas quase de imediato o mundo abandonado e substituído regressa na forma do próprio navio a vapor enquanto "Hotel Francfort com porteiro e tudo" (e mais adiante será mesmo o "Hotel Francfort de Santa Justa"), de tal maneira que este "nosso mundo" agora "outro" parece traduzir-se precisamente na experiência de um mundo em que nada coincide com o que é ou parece ser, um mundo em que a conversão por "outro" se apresenta como única modalidade de ser e em que "nosso" deixa de ser uma qualificação para se redefinir enquanto processo violento e incerto de 
apropriação do que realmente nunca deixa inteiramente de ser alheio.

Aquilo que vale contra a "banalidade" irredimível do navio, ou seja, o mar, a "água revolta", "em vagalhões cada vez mais cinzentos e maiores", é ele mesmo um valor ambivalente: coisa vital, animada de uma força própria (e, portanto, alheia a "nós") — como uma "grandeza" superior — é no mesmo lance "coisa ameaçadora" que transporta consigo para dentro do navio a ideia da morte e nele instala um inevitável e universal jogo de representação que a tenta afastar: "A ideia da morte não nos larga: separa-nos do caos um tabique de não sei quantas polegadas. Todos os passageiros se fingem despreocupados." (BRANDÃO, s/d., p. 10, itálico meu.) Em rigor, o mar é a figura do inapropriável e sê-lo-á ao longo de todo o livro, o que o opõe precisamente ao navio, que é não só desde logo redutível ao já conhecido e à banalidade como é ainda o espaço confinado de que se pode tomar posse. É o que sucede no segundo dia de viagem (9 de Junho de 1924) em que pela manhã Raul Brandão, o viajante, se vê tomado de "uma alegria frenética" perante os efeitos do "mundo sempre novo que [o] rodeia" (BRANDÃO, s/d., p. 11) e que são, no essencial e segundo uma lógica que estava já presente em Os Pescadores, efeitos da luz e sinais de uma "fotofilia" que nesse livro de 1923 é explicitamente elaborada². É por comunicação dessa "acção extraordinária" exercida pela "tinta azul" (BRANDÃO, s/d., p. 11.) sobre o viajante que este passa então à ação de tomar posse do navio na sua totalidade limitada feita de outras e mais pequenas totalidades limitadas que, no seu discurso, são inseparáveis da retórica da propriedade, no fio da qual a representação parcial das classes sociais que povoam o navio se enreda com uma espécie de naturalidade:

Tomo posse do barco. Primeiro é a vigia que me encanta, aquela pupila redonda e azul que me fita logo que acordo e por onde o mar espreita para dentro do camarote. Depois é a pequena cela toda branca onde todas as coisas estão nos seus lugares medidos e calculados. A cabina reduz de propriedade e a sua beleza geométrica consiste em não ter de mais nem de menos: é o espaço exacto para a vida do passageiro ou do frade. Quando saio do camarote acho-me logo no convés. Este mundo muito limitado corre-se nalguns minutos. No castelo da proa, entre cabos embreados, ceroulas penduradas numa corda, e gente de terceira classe, é que a vida pitoresca do barco se revela melhor. (BRAND ̃̃O, s/d., p. 11, itálicos meus)

Mas o próprio navio enquanto máquina viajante sofre de uma divisão social que tem de ser descrita e que lhe destrói a aparente identidade de mero e banal "Hotel Francfort" flutuante. Na verdade, também o navio é "outro", pelo menos duplo: "hotel e máquina ao mesmo tempo" (BRANDÃO, s/d., p. 11) que não se deixa conhecer sem exigir uma descida "ao interior" para "ver-lhe as tripas" (BRANDÃO, s/d., 11-12). Este corpo tem por dentro um motor e no trabalho desse motor está "a alma do transporte" (BRANDÃO, s/d., p. 12) cuja substância é o fogo. Estamos no exato contraponto da "frescura" com que se iniciara o relato da tomada de posse e a sumária explicação do funcionamento técnico que põe o fogo na "alma do transporte" desemboca na descrição da alimentação da fornalha do navio, como se nela se revelasse a infraestrutura laboral e social ocultada aos passageiros do "Hotel Francfort": 
Entreabre-se uma pequena porta de ferro e recuo sufocado. A tragédia do navio que se transformou em máquina está aqui: para que o hotel viva, digira e se mova, é preciso que alguém sofra. Estou dentro dum grande poço de ferro onde a atmosfera é irrespirável. [...] A luz vem de cima, claridade duvidosa e suja, e quando aqueles homens, que se agitam lá dentro, abrem a porta da fornalha, um jorro vermelho ilumina, cresta e deslumbra. [...] Fujo. Enquanto lá em cima todos nós vivemos no Hotel Francfort de Santa Justa, os outros cá em baixo vivem no Inferno. (BRANDÃO, s/d., p. 12)

Este movimento de desocultação socio-económica do "S. Miguel" é, por assim dizer, o primeiro passo propriamente etnográfico de As Ilhas Desconhecidas e é um passo cuja dimensão crítica não pode ser afastada da natureza do texto de Brandão sem o desfigurar profundamente. E o que aqui se define como dimensão ou força crítica também não pode de modo nenhum ser reduzido às intenções de um programa realista no sentido corrente, histórico-literário, do adjetivo. Se se trata de uma força articulada com a retórica do valor e com um certo tema económico que encontramos de início a fim do texto, o que nela se reconhece vai muito mais longe do que as proposições programáticas do realismo oitocentista, visto que reconduz, pelo menos, a um certo discurso sobre a desigualdade que é inseparável da emergência da própria ideia moderna de "literatura" durante a rede de acontecimentos escritos a que se chama comummente Romantismo.

\section{5.}

O laço entre literatura e etnografia (na verdade, o laço crítico que liga fatal ou vitalmente literatura e antropologia), que o texto de Brandão compõe desde o seu primeiro segmento "De Lisboa ao Corvo" e que estenderá até às páginas finais da sua derradeira sequência - "Visão da Madeira" -, tem de ser pensado enquanto enlace constitutivo daquilo que, entre os modernos, recebeu o nome de "literatura" mas também (e é a perturbação que textos como este regularmente causam e frequentemente se tenta iludir) daquilo que foi batizado e instituído com o nome de "antropologia". Fazer esta afirmação num ponto tão preliminar da leitura da narrativa pode parecer precipitado e, no entanto, é um protocolo indispensável cujo incumprimento explica, entre outras coisas, por que ordem de motivos um par de textos tão notoriamente cruciais para o entendimento da escrita de Raul Brandão quanto são Os Pescadores e As Ilhas Desconhecidas consegue passar pelo filtro dos exegetas e dos especialistas como se fosse uma excrescência ou uma curiosidade que se esgota em duas ou três notas de comentário marginal. Não surpreende muito. Uma tradição crítica genericamente governada por critérios de interpretação temática tem, com efeito, poucos instrumentos para poder enfrentar textos que põem em circulação e em jogo, não só a ideia, mas os limites da experiência literária. Ao mesmo tempo, a precipitação faz parte desse movimento de escrever ou reescrever os limites, que nunca são puros, do espaço literário. A proximidade do fim, a contiguidade ao desastre, a labilidade das distinções, a iminência do desenlace, incluindo aí o fim, por exemplo, da viagem enquanto tal, comprometem toda a possibilidade de hermenêutica puramente estética do discurso do viajante - quer dizer, ao mesmo tempo, puramente sensorial ou extática e puramente distanciada ou contemplativa. A oscilação, que se diria natural num texto governado pelo calendário como é em geral o destas 
"notas de viagem", entre dia e noite marca com uma regularidade todavia não codificada essa deriva entre sentido e caos que ainda no início (10 de Junho) tem esta explícita formulação, ao largo da Madeira:

Largamos e vem a tarde, vem a noite, e o cair da noite no mar é um espectáculo trágico. Este movimento que não cessa, das ondas avançando em colunas cerradas, umas atrás das outras, sempre, põe-me diante do que mais temo no mundo - do universo como mistificação e acaso... Lá vão as cores — as tintas — o doirado... Sou aquele fragmento de tábua que as ondas levam sem destino, sempre no mesmo negrume, no mesmo movimento perpétuo e inútil... Não é só a ameaça, a grandeza da noite, do mar, das vozes; é outra coisa pior que se afirma [...]. Com todas as suas complicações e o seu génio, as suas máquinas portentosas, com as suas ideias e a arquitectura que tem erguido e que chega aos céus - o homem, nestes momentos, sente que vale tanto como um cisco para esta coisa imensa e negra, para esta agitação incessante. Isto é pior que implacável, é pior que ameaçador: - não nos conhece. (BRANDÃO, s/d., p. 14-15, itálicos meus.)

Mais que o tom aparentemente pascaliano, importa sublinhar nesta nota a dupla inscrição do movimento, a transição da viagem para a deriva ou para a errância, que o mero "cair da noite no mar" produz: o acontecimento natural torna-se alteração do sentido, possibilidade de ler o universo "como mistificação e acaso", transfiguração do próprio viajante em "fragmento de tábua... sem destino". O anoitecer no mar faz entrar em cena a repetição do mesmo - o "mesmo negrume", o "mesmo movimento perpétuo e inútil" — e nesse sentido é que é "espectáculo trágico", o mundo repetindo-se e representando-se a si mesmo enquanto "agitação incessante", sem outro fim nem outra lei que a da repetição e prossecução do "movimento que não cessa". A alteração é suspensão ou retirada do sentido, o trágico não é a ação, mas a ausência do destino, a afirmação e o poder de outra coisa que decide o valor do homem sem sequer o conhecer. Esta antropologia negativa é de facto inseparável duma interrupção de todos os valores a partir de um ponto de vista que, desconhecendo-a, se afirma fora de toda a relação com a existência humana. O homem que, para tal escala, "vale tanto como um cisco" em rigor nada vale e sentir-se na presença dessa outra coisa é fazer a experiência do nada que interrompe, diariamente, a centralidade do homem para si mesmo, quer dizer, a narrativa implícita ou explícita em que o "homem" se toma por sujeito das suas obras. Não por acaso uma das palavras que sintetizam o humano neste excerto é "génio": o diálogo ou o desentendimento com o princípio e o primado da subjetividade romântica e, consequentemente, com a antropologia romântica (ou, para citar um título ressoante, com os "motivos românticos" do discurso antropológico ${ }^{3}$ ), é legível quase página a página no texto de As Ilhas Desconhecidas. Ao mesmo tempo, a antropologia negativa intermitente de Raul Brandão constitui outra versão ou outra leitura daquilo que etnograficamente, em sentido estrito, o viajante começou a praticar durante o trajeto "De Lisboa ao Corvo", quer dizer, esse desmantelamento crítico das aparências e das representações a que Foucault chamou, em páginas célebres, "a 
analítica da finitude" (cf. FOUCAULT, 1966, p. 351-357). Nessa versão, a finitude não é só a dos conteúdos empíricos das descrições etnográficas que Brandão constrói, analiticamente, para as diversas ilhas do arquipélago (ou dos dois arquipélagos, para ser mais exato), mas a finitude da experiência humana em geral enquanto afetada pela "tragédia" da repetição que lhe dissolve o sentido e lhe subtrai, não só o valor, mas o valor de verdade de todos os valores. "Outra coisa" (pior) é o nome reificado dessa repetição universal contra cujo movimento sem fim e sem finalidade a existência do "homem" já se não distingue pela necessidade ou pelo sentido, mas pelo acaso e pela insignificância. Isto é: já não se nota.

Poderíamos nós, em contraponto, notar a semelhança entre este apagamento noturno do "homem" sobre o fundo de uma "agitação incessante" que o ignora e aquele outro "próximo fim" que Foucault, animado pelos poderes de uma arqueologia do saber, antecipou apostando na hipótese de "que o homem se desvaneceria, como à beira do mar um rosto de areia" (FOUCAULT, 1966, 421-422)?

Talvez fosse melhor responder, a esta aproximação um pouco artificial, que o texto de Brandão pela sua deliberada inscrição na literatura de viagens, em cujo fio problemático a Europa viu nascer a "ciência" antropológica, mostra a dificuldade da aposta de Foucault se ela tiver de se suportar numa espécie de drama que opõe inconciliavelmente a literatura enquanto condensação e afirmação do "ser da linguagem" e o pensamento que toma o "homem" como seu objeto de inquirição privilegiado. Pelo contrário, livros como As Ilhas Desconhecidas tendem a documentar a solidariedade, mesmo que enigmática, entre a escrita que desde o romantismo quis dar corpo à ideia de "literatura" e o discurso de uma apurada (e porventura crescente) sensibilidade antropológica que, em Raul Brandão, está longe de se confinar às páginas desse livro. Mas é verdade que, no nó onde tal solidariedade se escreve e afirma quase como uma evidência, o "homem" deixou de ser uma natureza clara e de ter um valor seguro. É preciso, para o encontrar ou reencontrar, visitar lugares estranhos.

\section{6.}

"É com apreensão que desembarco no sitio mais pobre e mais isolado do mundo." Com esta frase termina o primeiro capítulo de As Ilhas Desconhecidas e trata-se de uma frase que não faz pouco para valorizar (ou hiperbolizar) a experiência narrada no capítulo seguinte, talvez o mais famoso de todo o livro. A ilha do Corvo é em certo sentido a ilha por antonomásia, o sítio confinado a si mesmo, o emblema do próprio isolamento: "Um penedo e vento na solidão tremenda do Atlântico." (BRANDÃO, s/d., p. 28)

Mas poderíamos igualmente dizer, sem cair em equívoco, o emblema do isolamento do próprio, isto é, da redução ao oikos, à propriedade, à casa, aos bens e, portanto, ao económico. Algumas das sínteses descritivas da ilha são quase puramente económicas, se uma qualificação destas pudesse fazer-se. Um parágrafo ainda no início:

Não há mercado nem estalagem. Não há médico, nem botica, nem cadeia. As portas não têm chave. Não há ricos nem há pobres, e neste mundo isolado tanto faz ser rico como pobre: o homem mais rico do Corvo anda descalço como os outros e lavra a terra com os filhos. O pedreiro é pedreiro e lavrador, o ferreiro é ferreiro e 
lavrador, e morre à fome quem não fabrica os currais por suas próprias mãos. Ninguém se sujeita a servir mas todos os vizinhos se ajudam: quando toca o sino a rebate, o povo acode a destelhar a casa, a construir a corte ou a levantar o socalco. (BRANDÃO, s/d., p. 28)

Pouco mais adiante, o reforço do testemunho pessoal que começa a entrar em detalhes: "Na verdade, não vi andrajos nem miséria. Ninguém pede esmola. Se um adoece, os outros lavram-lhe as terras. Aos mais pobres acodem-lhe com queijos para o sustento do ano e todos matam um porco." (BRANDÃO, s/d.., p. 29) Algumas páginas mais à frente, a fechar outro parágrafo onde estão em jogo várias formas de propriedade, esta estrutura social ao mesmo tempo autosuficiente e solidária recebe o seu batismo político depois de um juízo de valor que não implica, como um olhar desprevenido poderia supor, uma identificação projetiva por parte do viajante-etnógrafo: "Nunca vi como nesta ilha tão extraordinário sentimento de igualdade. O Corvo é uma democracia cristã de lavradores." (BRANDÃO, s/d., p. 34) Este modo de existência não é apresentado como um modelo, nem o uso dos verbos no famoso "presente etnográfico" chega a iludir o leitor no sentido de que o Corvo seja descrito como uma comunidade desprovida de história. Mais: essa história é posta na boca de um historiador local - o "senhor Manuel Tomás, de setenta e cinco anos" (BRANDÃO, s/d., p. 41) — que à noite conta ao viajante "o Corvo de outros tempos" que é, no essencial, um Corvo de fome depois corroborado em nota de rodapé por uma passagem do Portugal Contemporâneo, de Oliveira Martins, que relata um protesto dos corvinos pela escravização a que estavam sujeitos. Numa parte da narrativa do senhor Manuel Tomás, o dinheiro é expressamente o tema da descrição:

— Não havia dinheiro - continua o sr. Manuel Tomás. - Não se vendia nada, trocava-se tudo. Quem tinha uma casa a fazer, tocava o sino e a casa fazia-se num instante. Sabão, tabaco e pano azul traziam-no os baleeiros, e o povo dava-lhes cebolas e batatas. Os rapazes embarcavam no contrato da baleia, e as mulheres e os velhos é que faziam as terras. O mais que se comia era centeio, muito pouco, e junça. (BRANDÃO, s/d., p. 43)

No termo deste diálogo, o comentário parece imobilizar a comunidade no tempo, mas não deixa de imediato de lhe acentuar as alterações e de assim lhe retirar o valor de símbolo estático de um modo de vida: "Os costumes mudaram muito pouco. Ainda hoje os corvinos preferem trocar a vender. Só a ilha produz mais; produz tudo que esta gente precisa." (BRANDÃO, s/d., p. 45) A espécie de comunismo primitivo que parece poder inferir-se das palavras do informante identificado é, aliás, explicitamente abordada e negada pela insistência do narrador no tema da propriedade e na sua importância local: "O sentimento da propriedade é levado ao último extremo, até ao ponto de dividirem as ruas por cancelas, e campos de meia dúzia de metros quadrados por muros de pedra solta. Só há um vestígio de comunismo, que ninguém se recorda que existisse: a lã, que foi comum, é ainda hoje tosquiada em comum." (BRANDÃO, s/d., p. 45) Quase a fechar, a tensão entre propriedade e solidariedade como que se resolve pela redescrição da força passional que liga os corvinos uns aos outros e à ilha pela resistência ao 
isolamento de que eles mesmos são exemplo e efeito: "Estes seres isolados no mundo - unem-se. [...] Melhor: amam a sua ilha. Quando as raparigas embarcam para a América até das pedras se despedem abraçando-as. O Corvo é um mundo." (BRANDÃO, s/d., p. 49) Poderia ser esta a frase final do capítulo, mas Raul Brandão acrescenta-lhe, em corpo mais pequeno, uma nota suplementar que interpreta a frase literal ou informativamente: começa pela população exata (660 habitantes), pelo registo da baixa natalidade superada por uma mortalidade um pouco maior, pela afirmação não documentada de que a consanguinidade faz com que haja "bastantes doidos". Prossegue passando da demografia ao trabalho de campo do viajante, que leu "todos os papéis da administração" e confirma que "não há notícias de crimes" (BRANDÃO, s/d., p. 49), para depois registar em números precisos, isto é, em preços específicos, o baixo custo de vida no Corvo. O último parágrafo deste suplemento, na linha da nota que citava Oliveira Martins, relembra que a economia do Corvo está afinal em relação com a economia de Portugal, por um lado dizendo que os corvinos "não querem nada do Estado senão uma bateria eléctrica que falta no posto da T.S.F. para poderem comunicar com o mundo" (BRANDÃO, s/d., p. 49), por outro, assinalando consequências de só durante o Verão o vapor acostar à ilha ("porque o acesso é difícil"), em especial a de lhes permitirem nesses meses "embarcar o gado" que exportam para o continente. E a circunstância, propriamente económica, em que tal embarque é feito merece, em itálico, o derradeiro destaque crítico do viajante num dos poucos "retoques" que o texto final deixa reconhecer como tendo sido feito na composição do livro: para deixar anotado que aquele gado "vem sem preço para Lisboa, e é aqui vendido por o máximo, sendo-lhes remetido pelo agente o que ele thes quer mandar." (BRANDÃO, s/d., p. 50)

Nenhuma outra ilha merecerá de Brandão este género de preocupação material, que dá à etnografia do Corvo um caráter e um lugar especial pelo modo como insiste na análise da dimensão económica em estreita associação com a reflexão sobre o tipo de existência humana que os corvinos estão mais ou menos obrigados a levar, se não emigrarem (e este suplemento inclui, logo no parágrafo demográfico inicial, duas importantes especulações a esse respeito: "Se a América abrisse as portas fugia tudo. Ainda assim dentro em pouco o Corvo deve estar despovoado." Cf. BRANDÃO, s/d., p. 49). Também nenhuma ilha parecerá a Brandão tão humanamente estranha e nenhuma outra o fará escrever o que escreve quando condensa na tradicional metáfora do "pão", redescoberta como se acabasse de ser inscrita pela primeira vez, a luta pela sobrevivência que domina sem apelo a vida dos corvinos:

[...] Também só aqui entrou em mim como uma realidade o que esta palavra quer dizer: o pão. O pão é preciso arrancá-lo à pedra ou morrer no meio do oceano amargo. Tudo isto é certo — tudo isto comove — tudo isto me não basta. Sinto-me encerrado num presídio e a minha vontade é fugir: a vida monótona tem uma grandeza com que não posso arcar. Já não suporto a existência natural. (BRANDÃO, s/d., p. 48, itálico no texto)

Na verdade, há muito pouco de "natural" na existência corvina, tal como Brandão a descreve tentando não mitificar, explicitamente contra Rousseau ou contra o que Rousseau significa, a vida "do homem subjugado pelas necessidades 
elementares sobre a fraga no meio do mar, para dela extrair o necessário à vida, sem poder levantar a cabeça!" (BRANDÃO, s/d., p. 35) É significativo que este viajante repita, a propósito da "vida monótona" de que quer fugir, quase exatamente a mesma frase que tinha escrito a respeito das ondas que se sucediam na noite do oceano Atlântico entre Lisboa e o Corvo: "uma grandeza com que não posso arcar". A vida confinada ao pão, subjugada à necessidade, significa de novo o império esmagador da repetição, mas a experiência de contacto com a repetição humana no "tremendo isolamento" do Corvo traz ao viajante uma perceção nova, o conhecimento de um fator, de um elemento ou de uma força que fora dali não se fazia sentir: "É aqui que o Tempo assume proporções extraordinárias. [...] O Corvo não tem peso no mundo, mas nunca senti como aqui a realidade e o peso do Tempo." (BRANDÃO, s/d., p. 34) É este peso do Tempo reificado, tornado coisa sensível, "que no Corvo preside a todos os actos da vida" (BRANDÃO, s/d., p. 34), o poder ou a grandeza que permite afinal qualificar ainda como "natural" essa vida com cujos protagonistas se quer medir, como quem decifra "problemas insolúveis" (BRANDÃO, s/d., p. 34), a curiosidade antropológica de Raul Brandão num texto cuja retórica diarística é no entanto, também ela, ao menos à superfície, regulada pela mesma força. $\mathrm{O}$ envolvimento desta sensação do Tempo como entidade tornada real para o narrador da viagem não acontece sem antes o encontro com os corvinos face a face ser relatado ou, melhor, comentado como um encontro com a própria História, em que os interlocutores são "figuras de outro século, falando uma língua desenterrada” (BRANDÃO, s/d., p. 32) independentemente do estatuto social ou mesmo da idade que tenham: "Pertencem a outras idades. [...] Quase me metem medo, como se o passado se pusesse a olhar para mim e a interrogarme.” (BRANDÃO, s/d., p. 33) Esta prosopopeia do passado histórico que parece querer interpelar o viajante ganha rápida e inesperadamente a face de um espectro que é como que a representação da própria autoridade histórica, o espectro de Alexandre Herculano: "Quase me acusam (ou sou eu que me acuso?) da minha frivolidade. Um destes lavradores parece Herculano e outro tem mãos enormes e gretadas, mãos de terra quase desumanas." (BRANDÃO, s/d., p. 33)

O olhar alegorizante de Raul Brandão neste passo parece deslocado de qualquer intenção séria de conhecer os açorianos por aquilo que são, trocandoos livremente por fantasmas que obcecam esse olhar enquanto olhar de escritor (e de português) moderno. Mas esta intrusão do tempo das notas - quer dizer, do tempo da escrita ou da literatura - na experiência do tempo humano em nada impede o narrador ou o viajante, sendo que a distinção entre um e outro se torna aqui supérflua para não dizer absurda, de ver as "mãos enormes e gretadas" de um dos lavradores, assim como não o impediu antes nem o impedirá depois de distinguir os nomes e a individualidade concreta e viva dos corvinos com quem conversou. E a evidência com que essa percepção se impõe também não basta para afastar os atos de interpretação sem os quais nenhum conhecimento desta comunidade é possível: ver o que está presente e vivo não contradiz a conclusão de que o que "está vivo diante de mim é a história, é o passado. São os homens da fala e do acordo, os parlamentos que se juntavam ao ar livre nos adros, na velha terra portuguesa [...]" (BRANDÃO, s/d., p. 33). A personificação da história no fantasma direto e indireto da autoridade moral de Herculano e da tradição nacional que o seu nome, enquanto nome de historiador, representa, outorga um tanto paradoxalmente aos lavradores do Corvo o estatuto de interlocutores num plano que é mais de superioridade do que de igualdade. É como se o conceito mesmo de valor encarnasse nestes homens para desencadear no viajante a necessidade de 
interrogar a tábua de valores pela qual se governa. Não se trata só de um exame de consciência desencadeado por esta espécie de super ego histórico que, à semelhança da voz narrativa de Herculano nas Lendas e Narrativas, acusa o sujeito moderno, urbano, de "frivolidade" (o que pode sempre substituir-se pela má consciência do sujeito moderno que afinal se acusa a si mesmo). Trata-se antes de um confronto consigo mesmo, de uma reinscrição histórica e de uma revisão de pensamento induzidas pelo contacto, neste lugar, com estes homens que vivem "fazendo todos os dias os mesmos gestos e repetindo sempre a mesma meia dúzia de palavras até à morte" (BRANDÃO, s/d., p. 33)

A diferença do viajante - e daí sem dúvida a sua possível condição de frívolo como também o seu desejo de fugir — está nisso que, viajando, não faz todos os dias os mesmos gestos e, escrevendo, decerto não repete sempre e só (economicamente) a mesma meia dúzia de palavras. Estes homens não surgem, pois, diante dele como meros "objetos" de curiosidade ou simples habitantes de uma paisagem adversa: "Erguem-se diante de mim, e arredo tudo, esqueço tudo para os interrogar. Não que eles me saibam responder — eu é que hei-de responder a mim próprio, porque foi isto que me trouxe ao Corvo." (BRANDÃO, s/d., p. 34-35) É, assim, na experiência do Corvo que o viajante descobre aquilo que o trouxe ao Corvo, é na experiência da viagem que descobre o sentido da viagem, e é perante os corvinos que descobre a necessidade de interrogar e ouvir os corvinos para se entender ou se explicar a si mesmo. Se nos corvinos nada permitisse projetar o olhar alegórico que os alucina em emblemas da história e do passado ${ }^{4}$, em figuras de um Portugal que já não é o de Brandão, mas está em Brandão pela memória de Herculano (não primeiro, mas talvez segundo etnógrafo de Portugal, depois de Garrett, como Barthes disse algures que Michelet inaugurou a etnografia da França), nunca eles se ergueriam no texto deste relato com o poder de pôr em crise, em jogo, em questão e em movimento a identidade daquele que o escreve. Estas "figuras despidas e trágicas" (BRANDÃO, p. s/d., p. 34) são, nesse sentido, insubstituíreis e o valor da existência que levam mede-se pela dimensão espectral que alcançam e sem a qual nada, para este viajante, tem valor ou faz sentido. Porque é, afinal, no confronto com tal existência que uma asserção de essência, valendo por uma assinatura, declara, contra a economia, o nome do bem que nenhuma economia substitui: "Ora na vida o essencial não é o pão, é outra coisa sem a qual mais nos valia morrer. $\mathrm{O}$ essencial é o sonho que transforma o homem." (BRANDÃO, s/d., p. 35; itálico meu.) Uma anotação final só para sugerir que a ironia pela qual esta asserção não se lê hoje sem uma leve aura de banalidade a rodeá-la é talvez uma das suas provas de verdade. Outra é que não se substitui nesta frase a palavra sonho (por exemplo, por ideal, imaginação, desejo, etc.) sem que nela se perca alguma coisa de decisivo para a ideia, menos evidente do que aparenta, de que o essencial para a humanidade é o que na humanidade está para ser. 


\section{NOTAS}

1. Cf. Dicionário Houaiss.

2. No trabalho anterior que já mencionei, chamei "fotofilia" a essa paixão dos que, como se lê no capítulo de Os Pescadores dedicado à Ria de Aveiro, "amam a luz acima de todas as coisas" (BRANDÃO, 1986, p. 64). Brandão inclui-se entre esses e a inclusão não deixa de se reforçar por uma espécie de hipérbole que é económica na medida em que se refere ao sustento e à necessidade: “[A luz] É-me mais necessária que o pão." (BRANDÃO, 1986, p. 64) A referência a Os Pescadores permite-me lembrar aqui que um dos capítulos desse livro também organizado como relato de viagem se intitula "Pequenas Notas".

3. A alusão é a um dos mais importantes volumes da série "History of Anthropology" dirigida por George W. Stocking Jr.: Romantic Motives: Essays on Anthropological Sensibility, The University of Wisconsin Press, 1989. E com efeito todos os textos que integram esse volume se poderiam invocar como importantes para enquadrar a leitura disto a que não seria ousado de mais chamar "a sensibilidade antropológica" de Raul Brandão, cujo rasto é co-extensivo a toda a sua obra. No quadro da pesquisa que levo a cabo no juvenil ELAB - Laboratório de Estudos Literários Avançados da FCSH-UNL, a reflexão e a escrita dos antropólogos tem sido da maior importância e permito-me, por isso, remeter, a propósito das questões do valor, para Graeber (2001) e Thomas (1991) duas leituras, lentas, que o ambiente do ELAB me tem facultado condições para fazer.

4. E essa alucinação corresponde, afinal, ao que Johannes Fabian designou e denunciou, no discurso etnográfico, como "negação da coetaneidade" (para ensaiar uma tradução que me parece melhor do que a que se pode encontrar no texto do antropólogo holandês incluído na importante antologia que Manuela Ribeiro Sanches organizou há poucos anos: cf. SANCHES, 2005, p. 63-100), mas justamente a lógica contingente da escrita de viagem mostra, quando lida em todas as suas nuances, como também se encontra no mesmo capítulo a negação dessa negação.

\section{REFERÊNCIAS BIBLIOGRÁFICAS}

BRANDÃO, Raul. Os Pescadores. Lisboa, Editorial Comunicação, 1986. . As Ilhas Desconhecidas: notas e paisagens. Lisboa: Perspectivas \& Realidades, $\mathrm{s} / \mathrm{d}$.

FOUCAULT, Michel. As Palauras e as Coisas. Lisboa: Edições 70, s. d.

GRAEBER, David. Toward an Anthropological Theory of Value: The False Coin of our own Dreams. New York: Palgrave, 2001.

RUBIM, Gustavo. Estrangeiro e amigo: Raul Brandão nas Ilhas Desconhecidas. In: FERREIRA, António Manuel (coord.). Lusofilias. Aveiro: Universidade de Aveiro, Departamento de Línguas e Culturas, 2008, p. 107-117.

SANCHES, Manuela Ribeiro (org.). Deslocalizar a Europa: Antropologia, Arte, Literatura e História na Pós-Colonialidade. Lisboa: Cotovia, 2005.

THOMAS, Nicholas. Entangled Objects: Exchange, Material Culture, and Colonialism in the Pacific. Cambridge / London: Harvard University Press, 1991.

(Recebido para publicação em 20/10/2009, Aprovado em I I/0I/20I0) 